\author{
Сорока Іван Іванович, \\ кандидат мистецтвознавства, \\ Київський національний університет \\ культури і мистецтв, \\ Київ, Украӥна \\ ivansoroka1@ukr.net \\ ORCID: https://orcid.org/0000-0002-0336-5481
}

\title{
ОСОБЛИВОСТІ ТЛУМАЧЕННЯ К. СТАНІСЛАВСЬКИМ ПОНЯТТЯ «ІЛЮСТРОВАНИЙ ПІДТЕКСТ»
}

\begin{abstract}
Мета дослідження - з'ясувати особливості розуміння i тлумачення К. Станіславським його поняття «ілюстрований підтекст»; визначити сутність, значимість та місце «ілюстрованого підтексту» в процесі сценічного спілкування актора; запропонувати власне розуміння та визначення мовного підтексту й довести його значущість як складника сценічного мовлення. Методи дослідження: аналітичний - для дослідження існуючих теоретичних тлумачень підтексту та його практичного застосування;компаративний - у зіставленні й порівняльному аналізі теоретичних і практичних тлумачень та застосувань підтексту; логіко-узагальнюючий для підбиття підсумків дослідження, формулювання висновків. Наукова новизна роботи полягає в уточненні технології процесу словесної дії актора-читця під час сценічного спілкування; віднаходженні того основного, що слугує дійсною необхідністю проголошення актором авторських слів, та $є$ спонукою до продуктивної і цілеспрямованої словесної дії; в осмисленні й тлумаченні сутності театрального поняття «підтекст» та застосуванні його у сценічній мовленнєвій практиці. Висновки. 3'ясовано, що К. Станіславський та продовжувачі його вчення трактують підтекст: як позатекстові - акторські бачення, уявлення, образи, думки, почуття, іменуючи ще його «ілюстрованим»; і як - наскрізна дія в галузі мовлення, не вбачаючи й не акцентуючи при цьому на їхній відмінності й різності. Наголошено, що враження від уявної «ілюстрації» («ілюстрований підтекст»)є лише подразником словесного спілкування актора; дійсну ж необхідність проголошення слів породжує мотивація та мета їх виголошення.

Ключові слова: словесне спілкування; «ілюстрований підтекст»; підтекст наскрізної дії; К. Станіславський; Г. Крісті;«кінострічка бачень»; внутрішні бачення; відчуття.
\end{abstract}

Творча уява, якою б дивовижною та фантастичною вона не була, випливає з життевого досвіду, з побаченого, почутого, пережитого. Надія Гуменюк, «Енна»

Постановка проблеми. У театральній педагогіці поняття «ілюстрований підтекст» зазвичай вважають головною передумовою перетворення тексту ролі на словесну дію, а основою «ілюстрованого підтексту» - бачення, які породжують відчуття. Засновник театральної теорії К. Станіславський 
розглядає процес осмислення, «привласнення» актором авторського тексту через ілюстрований підтекст і підтекст наскрізної дії, не акцентуючи при цьому на їхніх специфіках. Послідовники теорії Станіславського не намагаються самостійно розібратися в проблемі «ілюстрованого підтексту» й підтексту наскрізної дії, а слідують за його міркуваннями, переповідаючи чи цитуючи ïx, - не заперечують, не спростовують i власних аргументів не наводять. Проблема полягає в тому,що «ілюстрований підтекст» не $\epsilon$ основним у словесній дії: він існує лише як подразник і стимулятор до дії; виражає ж іï підтекст наскрізної дії промовляння.

Аналіз останніх досліджень і публікацій. Поняття «ілюстрований підтекст» пропонує й розглядає в своїх теоретичних роботах К. Станіславський. Частково апелюють до цього терміну теоретики i практики театру В. Сахновський, О. Попов, М. Кнебель, Г. Крісті, Г. Товстоногов, І. Промптова, В. Галєндєєв, В. Фільштинський. Серед українських театрознавців поняття підтекст, як категорію сценічного мовлення, розглядали Г. Юра в книзі «Режисер у театрі», М. Карасьов уроботі «Станіславський і сценічна мова» та Р. Черкашин у посібнику «Художнє слово на сцені». Всі названі дослідники, теоретики й практики театру тією чи іншою мірою розглядають явище сценічного підтексту загалом під кутом зору К. Станіславського, визнаючи й підтримуючи його тлумачення підтексту як «ілюстрований».

Мета статті - з'ясувати особливості розуміння i тлумачення К. Станіславським поняття «ілюстрований підтекст»; визначити сутність, значимість та місце «ілюстрованого підтексту» в процесі сценічного спілкування актора.

Виклад основного матеріалу. Як стверджує В. Галєндєєв у монографії «Не тільки про сценічну мову», усебічне осмислення механізмів «привласнення» актором авторського тексту привело К. Станіславського до найважливіших відкриттів: були сформульовані поняття «ілюстрованого підтексту» і «кінострічки бачень ролі» (2006, с.103). Сам К. Станіславський поняття «ілюстрований підтекст формулює так: «Природа зробила так, що ми в словесному спілкуванні з іншими людьми спочатку бачимо внутрішнім зором те, про що йде мова, а потім уже говоримо про те, що бачимо. Коли ж ми слухаємо інших, то спочатку сприймаємо вухом те, що нам говорять, потім бачимо оком те, що ми почули. Слухати нашою мовою означає бачити те, про що говорять, а говорити - значить створювати зорові образи. Слово для артиста не просто звук, а збудник образів. Через те в словесному спілкуванні на сцені говоріть не стільки для вуха, скільки для ока. Таким чином нам потрібен не простий, а ілюстрований підтекст п’єси і ролі» (туm $i$ далі у цимтатах виділення наше - I. С.) (Станіславський, 2008, с.69).

Досліджуючи явище «ілюстрованого підтексту» К. Станіславський наводить приклад із проголошенням міні-оповідання: «Я був зараз в Івана Івановича. Він у жахливому стані: його дружина втекла. Довелося їхати до Петра Петровича, розповісти про те, що сталося, і просити його допомогти заспокоїти бідолаху» (2008, с.69), яке не викликало довіри до жодного слова «і не дивно, - стверджує автор, - хіба можна промовляти їх щиро без розумових уявлень, створюваних вигадками уяви, магічним «якщзо б» і пропонованими обставинами? Необхідно знати й бачити їх своїм внутрішнім зором <...> Придумайте ж той вимисел 
уяви, магічне «якби» i запропоновані обставини, які дадуть вам право вимовити ичі слова. Мало того, ви не тільки дізнайтеся, але й постарайтеся ясно побачити все те, що образно, зримо намалює вам ваша вигадка уяви» (2008, с.69-70). Тільки за таких умов, стверджує К. Станіславський, чужі, задані слова стануть потрібними, необхідними, набудуть права на вимову. «Внутрішні бачення створять настрій, який викличе відповідне відчуття» (2008, с.70). Отже, «ілюстрований підтекст» у Станіславського - це «магічні та інші «якби», «запропоновані обставини», «всі зовнішні умови», усе «внутрішньо відчуте «життя людського духу» ролі, яке безперервно тече під словами тексту, весь час виправдовуючи й оживляючи їх» (2008, с.65). Саме вони, стверджує К. Станіславський, роблять чужі слова власними, необхідними.

Чи справді це так? Запропонований текст не міг пролунати органічно в устах учня, тому що за змістом ця «чиста» репліка-звернення природно вимагає, насамперед, адресата - партнера та усвідомлення мети ії виголошення. А для цього детальні бачення не $є$ першочерговими. У запропонованому Станіславським для вправи тексті відчувається підтекст словесної дії: «Ти розумієш? Ти усвідомлюєш усю біду і трагізм ситуації Івана Івановича?» I аж ніяк не: «Чи бачиш ти, чи уявляєш чітку, цілісну, до дрібниць реальну картину, в якій знаходиться Іван Іванович?» Та найголовніше: «що ж тепер буде, і чим ще можна йому допомогти?»- породжує дієвий підтекст і викриває мету промовляння, яка звучить за прямим змістом слів.

Митець стверджує, що під час спілкування повинні бути природні, необхідні людські завдання - «упроваджувати в інших свої бачення» (рос. «внедрять в другого свои видения») (Станіславський, 2008, с.71). Із цим важко погодитися. Природні й необхідні людські завдання в спілкуванні - доносити свою думку й домагатися мети спілкування. Бо, виходить, що при кожному спілкуванні ми тільки те й робимо, що переказуємо свої бачення, намагаючись будь-якою ціною змусити співрозмовника побачити їх і зажити ними разом 3 нами.

На підтвердження нашої незгоди звернімося до думки того ж К. Станіславського: «У житті майже завжди говорять те, що потрібно, що хочеться сказати заради якоїсь цілі, завдання, необхідності, заради справжньої, продуктивної і цілеспрямованої словесної дії. I навіть нерідко в тих випадках, коли базікають слова, не замислюючись над ними, роблять це для чого-небудь: щоб скоротати час, щоб відвернути увагу тощо» (Станіславський, 2008, с.63). Як бачимо, уже не йдеться про передачу бачень, переживань, а про донесення мети промовляння, про досягнення завдання мовної дії.

Ту ж подвійність спостерігаємо і в учня Станіславського Г. Крісті, який наголошує: «Щоб утримати себе на лінії підтексту при кожному повторенні творчості, потрібно щоразу переглядати створену в уяві «кінострічку бачень», 3 якою цей підтекст пов'язаний. Поєднуючи ці два поняття, Станіславський увів в театральний ужиток термін ілюстрований підтекст. Ілюстрований підтекст не $\epsilon$ ілюстрований текст, тобто образне бачення самих вимовлених слів. Це бачення, щуо виражають справжні думки, почуття й наміри дійової особи» (Крісті, 1968, с.166). Отже, за автором, ілюстрований підтекст - це бачення, що виражають справжні думки, почуття й наміри дійової особи. Напрошується логічне питання: як можуть бачення виражати абстрактні речі 
(думки, почуття, наміри)? Бачення можуть породжувати, а не виражати їх. Та найцікавіше, як можна баченнями виразити наміри дійової особи? Те, що автор заперечує, насправді саме таким i $\epsilon$. Ілюстрований підтекст це ілюстрований текст, образне бачення вимовлених слів 3 їх емоційним проживанням і вираженням. Поєднуючи два поняття - бачення і підтекст у «кінострічку бачення», автор саме цим поєднанням підтверджує їхню тотожність. Під текстом - «кінострічка бачення» - підтекстобачення 3 його відчуванням, переживанням.

Далі Г. Крісті розмірковує: «Без підтексту неможливо обійтися на всіх стадіях словесної взаємодії. Насправді, щоб привернути, наприклад, увагу партнера, необхідно мати певну мету і відповідні цій меті бачення, які я маю намір передати йому або уточнити в результаті спілкування з ним» (Крісті, 1968, с.169). Справді, щоб привернути увагу партнера, треба мати певну мету промовляння і прагнути саме іiі й досягти, бо ніколи не може слугувати метою передавання комусь своїх бачень, адже вони абстрактні, а мета завжди конкретна i, найголовніше, дієва. Як би актор не намагався чітко передати свої бачення, це все одно буде уявне, абстрактне бачення, яке не передати, тим більше не уточнити, бо партнер ніколи, ні за яких обставин не уявить те, що уявляв собі передавач. Та й самому передавачеві для найкращої передавання свого уявлення потрібно принаймні від усього відсторонитись і повністю сконцентруватися на своєму внутрішньому баченні а тоді весь процес взагалі втрачає всякий сенс, без оцінки і сприйняття реципієнта. Та й навіщо передавати те, що завідомо не передається і не може слугувати метою. Це все одно що слухати музику через навушники й водночас переказувати іiі партнеру, щоб той почув те саме.

Утім, Г. Крісті наполягає:«Внутрішня боротьба Гамлета протікає в зіткненні контрастних бачень, що особливо яскраво проявляється у центральному монолозі «Бути чи не бути»« (Крісті, 1968, с.169). Внутрішня боротьба Гамлета протікає в зіткненні контрастних морально-філософських поглядів, а не бачень. I далі: «Поза ілюстрованим підтекстом ніякого органічного процесу оцінки відбутися не може. Адже навіть футболіст посилає м'яч тому чи іншому партнеру залежно від того, як йому малюється подальший розвиток гри, які в його уяві складаються комбінації»(Крісті, 1968, с.169). «Малюються», «складаються комбінації» - автор веде мову винятково про уявні баченнякартини та їх передавання. Хіба можна уявити собі, що футболіст, отримавши м’яч і витрачаючи долі секунди на оцінку ситуації й обрання напрямку ударупасу, спочатку буде «малювати в своїй уяві різні комбінації», щоб, вибравши найкращу, продовжити розвиток гри.

Розглядаючи сценічний процес, Г. Крісті в руслі К. Станіславського розмірковує:«Відбувається не тільки прилаштування до об’єкту, але й налаштування самого об'єкта для впливу на нього. Іншими словами, потрібно добре налаштувати екран внутрішнього зору партнера, щоб проектувати на нього свої бачення» (Крісті, 1968, с.170).

Автор розбирає монолог Чацького:

Я ж стрімголов летів через весь світ,

За сорок п'ять годин, не спавши ні

хвилини,

Більи як сімсот верстов промчав 
у хуртовину,

В дорозі все згубив, і падав скільки раз -

I от яка мені відрада!

Аналізуючи уривок, Г. Крісті стверджує: «ці слова малюють внутрішні бачення Чацького, які він передає Софії» (Крісті, 1968, с.171). У Крісті «ілюстрований підтекст» монологу героя розуміється таким:

Забувши про себе,

Я изілих дві доби не спав,

Проїхав миль більше семисот,

Перетерпів і вітер й бурю,

Втомився весь, шоразу падаючи -

А вам мене ні трішечки не жаль!

Та хіба, зізнаючись у коханні, герой буде передавати дівчині якісь свої бачення, 3 кожним словом пересвідчуючись, що вона його не кохає? Передавання «внутрішніх бачень» (складної дороги, важких умов, величезної втоми) може викликати лише жаль та співчуття, а не те, чого хоче Чацький. Мета Чацького - переконатись, дізнатись, чи кохає його Софія. Його слова так і кричать підтекстом:

Я так люблю вас! Не тямлячи себе,

Забувши про час і сон,

Про відстань і негоду,

Спішив переконатись, щзо ви - теж!?

...Та ви мене не любите!

Ми переконані, що в наведеному уривку героєм не малюються жодні внутрішні бачення, не переглядається ніяка «кінострічка бачень», а передано підтекст у варіанті прихованого змісту - зізнання. Як не дивно, про це мимоволі говорить і автор: «Софія не просто не діє і не тільки сприймає його слова, але і бореться з ним, висловлюючи своє здивування, незгоду, протест, нетерпіння та ін., відкидаючи його іронічний тон, захопленість, любов» (Крісті, 1968, с.173). Отже, Софія відкидає не бачення Чацького, а його любов, зізнання прихованих у підтексті іронічним тоном, про що ми й ведемо мову.

Справжні пережиті бачення можуть бути тільки в реальному житті, де ми переживаємо природні емоції життєвих радощів, драм і трагедій. Найяскравіші події нашого життя назавжди відкладаються в пам'яті і насамперед у формі вражень, емоцій, почуттів. Тільки вони є причиною того, що в нашій пам’яті починають проявлятися окремі нечіткі картини пережитих бачень.

Звернемо увагу: говорячи про бачення, ми завжди говоримо саме про пережиті бачення, а не побачені бачення; і це не для уникнення тавтології, а саме тому, що «пережиті»- означає саме відчуті, а не просто побачені. Наприклад: що першим спливає у нашій пам'яті при слові «мама»? Конкретне бачення чи емоція? Швидше за все, нас моментально охоплює емоція, враження, уся невимовна і не передана словами гама почуттів, пов'язаних iз найдорожчою людиною, наше особисте сприйняття іiі, а вже потім виникає внутрішнє бачення безпосередньо образу матері. Цей образ ми бачимо своїм внутрішнім зором, він спливає в нашій зорової пам'яті, ми внутрішньо концентруємося на ньому, але при цьому продовжуємо бачити все те, що нас оточує. Образ матері створюється поєднанням емоційної та зорової пам’яті, але 
емоційна при цьому набагато сильніша, і саме вона визначає особливість і характер спілкування. Цей образ для кожного 3 нас рідний, близький, дорогий i добре відомий. А що говорити про неіснуючі, нафантазовані картини наскільки вони можуть бути чіткими й викликати якісь емоції? Актор завжди може покластися винятково на свій життєвий досвід, свої бачення, які може відтворити його пам'ять. I які б реальні чи нафантазовані бачення не застосовував виконавець, все одно в їхній основі будуть образи із власного життя, які далеко не завжди можна підкласти під зображену автором картину чи подію, не кажучи вже про сюжети, далекі в часі або 3 життя маловідомих соціальних груп. То чи можуть створені, нафантазовані уявою картини бути головними й вирішальними в мові, чи слід орієнтуватися на щось більш значуще, що можна застосувати в усіх без винятку ситуаціях? Спробуємо знайти відповідь.

У наведеному вище прикладі була представлена наша безпосередня реакція на почуте слово «мама». А тепер простежимо, що відбуватиметься під час його вимовляння. Ми вкладемо в його звучання наше бачення материнського образу чи 3 усіх сил намагаємося всіма засобами передати гамму наших почуттів та емоцій, пов’язаних 3 образом найдорожчої людини? Та найголовніше - для чого ми ділимося своїми сокровенними почуттями? Явно не для того, щоб партнер чітко уявив образ нашої матері, що неможливоз робити, а переслідуємо мету - висловити свою любов до матері, і саме це ми повинні донести, а співрозмовник усвідомити, а не побачити.

На відміну від реального життя, актор на сцені не грає себе, він існує в іншому часі, навколо люди та події не з його життя. Про який «ілюстрований підтекст», бачення й переживання «прожитих» років героя може йти мова? I чи може актор так усе нафантазувати, щоб потім, користуючись цими баченнями («кінострічкою бачення»), тримати їх внутрішнім зором, водночас промовляючи слова, які ці бачення не означують? Навіть у випадках пригадування, переказу й фантазування словесна дія має за мету впливати на партнера надзавданням i не може виражатися в передаванні відчуттів та викликанні переживань. Який «ілюстрований підтекст» для репліки в теперішньому часі «Я кохаю тебе»? Які бачення можна підкласти, щоб домогтися ілюстрованого підтексту? Нічого цього немає. Нами буде керувати надзавдання, яке породить дію, - зізнатися в коханні; ми трепетно будемо чекати відповіді, а не реакції на неіснуючі бачення.

Наукова новизна дослідження полягає в тому, що в статті вказується на двоякість розуміння процесу словесної дії актора-читця під час спілкування в теоретичних напрацюваннях засновника театральної теорії К. Станіславського та його учня Г. Крісті; виокремлюються розбіжності в їхніх теоретичних дослідженнях i доводиться власне тлумачення означеної проблеми й театрального поняття «підтекст» у сценічному мовленні.

Висновки. Нині спостерігається різне тлумачення процесу словесної діï і іiі завдання. По-перше: «внутрішнє бачення створює настрій, який викликає відчуття», що виявляється в проголошенні авторських слів, роблячи їх наповненими настроєм та переживанням, називається «ілюстрованим підтекстом». По-друге: промовляння «заради цілі, завдання, необхідності, заради справжньої,продуктивної і цілеспрямованої словесної дії» - підтекст 
наскрізної дії промовляння. Відповідаючи на поставлене вище питання стверджуємо: дійсну необхідність проголошення слів породжує не передавання внутрішніх бачень 3 їх емоційним відчуванням та проживанням, що приводить до награвання станів, емоцій, а донесення мети їх виголошення - спонукає до продуктивної і цілеспрямованої словесної дії. Мета і завдання проголошених слів, які звучать, чуються, розуміються одночасно зі змістом, становлять підтекст наскрізної дії промовляння.

Має рацію В. Галендєєв: «Мабуть, ні 3 одним поняттям «системи» К. Станіславський не бився стільки, скільки 3 підтекстом, намагаючись визначити його якнайглибше і якнайвичерпніше. I все ж, якщо бути чесним, цілком конкретного й однозначного формулювання, що відмежовує це поняття від інших, властивих «системі» («кінострічка бачень» як ілюстрований підтекст, наскрізна дія, що часто сприймаюся синонімом підтексту й ін.), йому дати не вдалося» (Галендеев, 2006, с.115). Про це ведемо мову й ми в цій статті, в інших своїх дослідженнях (Сорока, 2014, 2015) та в цьому ж плані визначаємо подальші наукові перспективи.

\section{Список посилань}

Галендеев, В.Н., 2006. Не только о сиенической речи. Санкт-Петербург: СанктПетербургская академия театрального искусства.

Кристи, Г.В., 1968. Воспитание актера школь Станиславского. Москва: Искусство. Никулин, С.К. и Пичхадзе, Л.А. ред., 2008. Искусство режиссуры XX век. Москва: Артист. Режиссер. Театр.

Сорока, I.I., 2015. «Ілюстрований підтекст» у тлумаченні К. Станіславського та послідовників його школи. Актуальні проблеми історї, теорії та практики художньої культури, 34, с.363-370.

Сорока, I.I., 2014. Суперечність у визначенні К. Станіславським поняття «підтекст»: на матеріалі праці І. Промптової. Художня культура. Актуальні проблеми, 10, с.110-115.

\section{References}

Galendeev, V.N., 2006. Ne tolko o stsenicheskoy rechi [Not just about stage speech]. St. Petersburg: Sankt-Peterburgskaya akademiya teatralnogo iskusstva.

Kristi, G.V., 1968. Vospitanie aktera shkolyi Stanislavskogo [Education of the actor of the Stanislavsky school]. Moscow: Iskusstvo.

Nikulin, S.K. and Pichhadze, L.A. eds., 2008. Iskusstvo rezhissuryi XX vek. [The art of directing the twentieth century]. Moscow: Artist. Rezhisser. Teatr.

Soroka, I.I., 2015. «Iliustrovanyi pidtekst» u tlumachenni K. Stanislavskoho ta poslidovnykiv yoho shkoly [«Illustrated Subtext» in the interpretation of K. Stanislavsky and his school’s followers]. Aktualni problemy istorii, teorii ta praktyky khudozhnoi kultury, 34, pp.363-370.

Soroka, I.I., 2014. Superechnist u vyznachenni K. Stanislavskym poniattia «pidtekst»: na materiali pratsi I. Promptovoi [The contradiction in the definition of K. Stanislavsky's notion of «subtext»: on the material work of I. Propptova ]. Khudozhnia kultura. Aktualni problemy, 10, pp.110-115.

(C) Сорока I.I., 2018 


\section{Soroka Ivan, PhD in History of Arts, Kyiv National University of Culture and Arts, Kyiv, Ukraine}

\section{PECULIARITIES IN THE INTERPRETATION OF K. STANISLAVSKY CONCEPT «ILLUSTRATEDSUBTEXT»}

The purpose of the study is to find out the features of understanding and interpretation of K. Stanislavsky's concept of «illustrated subtext» to determine the essence, significance and place of «illustrated subtext» in the process of stage interaction between the actors. To offer own understanding and definition of a language subtext and to prove its significance as a composite scenic speech. Research methods. Analytical is to study existing theoretical interpretations in the context and its practical application; comparative has been used in comparing and comparative analysis of theoretical and practical interpretations and application in the subtext; Logical-generalizing is for summing up the research, formulation of conclusions. The scientific novelty of the article is to refine the technology of the verbal action of the reader's actor during stage communication; finding the main one, which serves as a real necessity for the declaration of the author's words by the actor, and is an inducement for productive and purposeful verbal action. In the comprehension and interpretation in the essence of the theatrical notion in «subtext» and its application in the stage of speech practice. Conclusions. It is pointed out that K. S. Stanislavsky and his followers interpret the subtext as out-of-text is actor's vision, representation, images, thoughts, feelings; calling it «illustrated», and as a subtext of a through action, it is not emphasizing at the same time their differences and distinctions. We note that the impression of the imaginary «illustration» («illustrated subtext») is only an irritant to verbal communication between the actors; the real need to pronounce words generates motivation and the purpose of their pronouncement.

Key words: verbal communication; «illustrated subtext'; subtext of the through action; K. Stanislavsky; G. Christie; 'film tape of visions»; internal vision; sensation. 
Сорока Иван Иванович, кандидат искусствоведения, Киевский национальный университет культуры и искусств, Киев, Украина

\section{ОСОБЕННОСТИ ТОЛКОВАНИЯ К. СТАНИСЛАВСКИМ ПОНЯТИЯ «ИЛЛЮСТРИРОВАННЫЙ ПОДТЕКСТ»}

Цель исследования - выяснить особенности понимания и толкования К. Станиславским его понятия«иллюстрированный подтекст»; определить сущность, значимость и место «иллюстрированного подтекста» в процессе сценического общения актера; предложить собственное понимание и определение речевого подтекста и довести его значимость как составной сценической речи. Методы исследования: аналитический - для исследования существующих теоретических трактовок подтекста и его практического применения; компаративный - при сопоставлении и сравнительном анализе теоретических и практических толкований и применения подтекста; логикообобщающий - для подведения итогов исследования, формулирование выводов. Научная новизна работы заключается в уточнении технологии процесса словесного действия актера-чтеца во время сценического общения; нахождении того основного, что служит действительной необходимостью провозглашения актером авторских слов, и является побуждением к продуктивному и целенаправленному словесному действию; в осмыслении и истолковании сущности театрального понятия «подтекст» и применении его в сценической речевой практике. Выводы. Установлено, что К. Станиславский и продолжатели его учения трактуют подтекст: как внетекстовые актерские виденья, представление, образы, мысли, чувства, называя еще его «иллюстрированным»; и как - сквозное действие в области вещания, не видя и не акцентируя при этом на их различия и разности. Отмечено, что впечатление от мнимой «иллюстрации» («иллюстрированный подтекст») является лишь раздражителем словесного общения актера; действительную же необходимость произнесения слов порождает мотивация и цель их произнесения.

Ключевые слова: словесное общение; «иллюстрированный подтекст»; подтекст сквозного действия; К. Станиславский; Г. Кристи; «кинолента видений»; внутренние видения; ощущения. 